\title{
SEMANTIC ANALYSIS OF FRAUDULENT ADS IN FACEBOOK
}

\author{
Burhanudin Rais, Pratomo Widodo
}

\author{
burhanrais88@gmail.com \\ Yogyakarta State University \\ Sleman, Yogyakarta, Indonesia
}

\begin{abstract}
This study aims to analyze the semantic features in fraudulent ads on Facebook. This study is conducted by using two kinds of advertisement found on Facebook. The words, sentences, or phrases to convince the customers were analyzed by following Leech's theory of meaning (1981). The result showed that the first type of advertisement is emphasized more on the affective and social meaning, where the seller leads the customers' opinion that the seller is a good or trusted person. Moreover, the seller uses phrases that include conceptual meaning to explain the condition or specification of the cellphone in detail. In the second type of advertisement, the element emphasized by the seller is thematic meaning by referring to the emphasis of the word used in the advertisement. Moreover, the result for the identification of fraudulent ads in this study is still dominated by the usual way, such as by looking at the price offered. However, the results of this study can also be used as a consideration in identifying fraudulent ads.
\end{abstract}

Keywords: Facebook, Fraudulent Ads, Semantic Analysis

\section{INTRODUCTION}

The development of technologies becomes one of the characteristics of today's era, such as the development of gadget, which increases very fast. Those developments are along with the development of applications. The researchers defined an application as the program that can be accessed by the users in their gadget, such as mobile phone, PC, tablet, etc. Social media is the kind of application accessed on those types of gadget. There are many kinds of social media; one of them is Facebook.

Facebook is the application created by Mark Zuckerberg, which at first was only intended as a social network that can link Harvard students to each other (Hastuti, 2011). Along with its development, Facebook is used as a social network that can be used by all people in various parts of the world. The users can share a moment or write their thought (status).

Along with the development, the use of Facebook in today's era is not only for sharing moment or status but also uses for business. Facebook becomes one of the superior applications for business (Baktiono \& Aryata, 2016) as it has a big number of users in the world, including Indonesia. It certainly opens opportunities for promoting and finding new customers. Someone can create a group or fan page or write a status for selling the product. As known that business activity is about selling and buying; of course, it is not that simple. In this context, the researchers only emphasized on selling activity.

In a selling activity, the use of advertisement can take effect on the business. Concerning Facebook as a social media for business, it is useable for advertising. According to Dunn and Barban (as cited in Watie 2016) advertising is a form of nonpersonal communication activity conveyed through the media by supporting the space, it uses to convey persuasive messages to consumers, by companies, non-commercial organizations, and individuals who have an interest. This statement is quite different from 
Facebook. In Facebook, advertisements can be made personally. The seller who advertises his product on Facebook does not need to have a company.

With the increasing sales trending through Facebook, it makes various things can be bought through Facebook. However, this also provides a negative gap that is used by some dishonest people. This crime is called cybercrime, that arises because of the use of internet technology (Sumenge, 2013). With the increasing number of requests for internet access, crimes against the use of information technology are increasingly following the development of the technology itself.

According to data from Kompas.com that was written by Arnani, (2018), there were 16,678 reports of fraud online on 11 September 2018. It means that the Indonesian people are not aware of identifying the fake advertisement. Moreover, according to the preliminary observation, one of the methods to identify fake advertisements is by looking at the prices offered. The fake or fraudulent advertisement is suspected when it offers a very low price. However, not all fake advertisements use this price-lowering technique. Thus, it needs another way to identify fake advertisements, especially from the language aspect.

Moreover, the previous studies which concern the ads only analyze the language features, not to the fraudulent ads. Such as the research conducted by Rinanda (2012). In her research, she describes the type, structure, and meaning of the sentences on the telecommunication provider brochure. Second is the research conducted by Mardani et al. (2017) describing the phrase, clause, sentence, morphological structures, and persuasive power of Sampoerna A-Mild cigarettes advertisement. Another study is conducted by Lazfihma (2014), who describes the style of language used and the meaning contained in the slogan in the tea and coffee drink ads on television.

This research is different from previous studies as it focuses on the linguistic feature of fraudulent ads on Facebook to see the possibility of language prevention efforts by reviewing the semantic features.

\section{LITERATURE REVIEW}

The semantic word comes from the Greek "Sema" means sign or symbol. In the form of a verb, the word sema becomes semaino which means "mark" or "symbolize". In linguistics, the sign is interpreted as a linguistic sign. Semantic is then agreed as a term used in the field of linguistics, namely the relationship between linguistic signs and things marked. Therefore, semantics can be interpreted as a science of meaning or about meaning (Chaer in Djojosuroto, 2014). Semantic as the branch of linguistic concerns to discuss meaning (Verhaar, 2016).

Tarigan (as cited in Djojosuroto, 2014) adds that language is consists of structures that show meaning when connected with other objects in the world. Some factors need to be known to determine the meaning of a word. Chaer (2009) divided them into five factors which consist of lexical meanings of words that form the sentences, word sequences in organizational sentences, intonation; the way the sentence is pronounced or written, the context of the situation of the sentence is pronounced, the sentence before and after that accompanying the sentence and others. Therefore, all the type of language that produces both in written or spoken has a meaning. Such as sentence in the Indonesian language below (1), The word "manis" lexically refer to something sweet such as "sugar", instead of the word "manis" in that sentence defined as "beautiful" or "kind".

\section{(1) Gadis itu sangat manis rupanya}

In the study of semantic, it is also associated with social science such as sociology and anthropology, and also philosophy and psychology (Chaer, 2009). Moreover, Chaer (2009) adds that culture is also associated with the study of semantics. For example, the word ikan in Indonesian language and has the meaning "fish" in English. While the word iwak in the Javanese language means fish and side dish.

Meaning is an inseparable part of semantics and is always inherent from the utterance. In general terms, the meaning of a sentence depends on the relationship between the words and morphemes they contain and the meaning contained by the combination. Leech (1981) adds, the meaning is divided into 
some parts. Those parts consist of conceptual, thematic, and associative meanings.

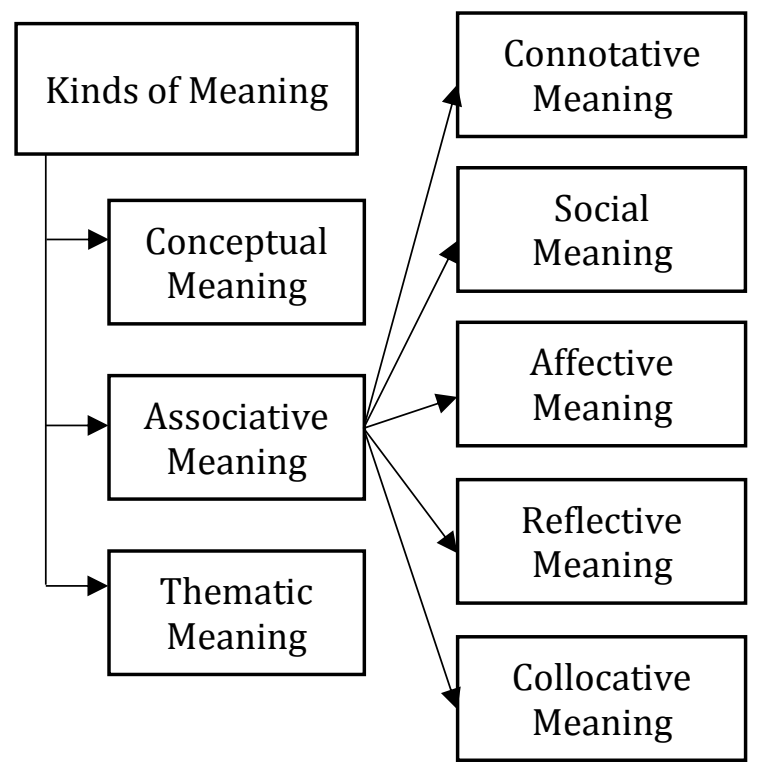

Figure 1. Types of Meaning by Leech (1981: 23)

\section{Conceptual Meaning}

Conceptual meaning, which also known as denotative meaning, is the real meaning or meaning that emphasizes the definition of meaning itself (Leech, 1981). Chaer (2009) stated that conceptual meaning refers to the meaning possessed by a word regardless of any context or association. For example

(2) Toni sat on the chair, behind the door

The word "chair" in the sentence above refers to the real meaning. It only has a meaning as an object to sit.

\section{Associative Meaning}

Associative meaning is the meaning related, connected, associated with certain things outside the language (Chaer, 2009). Such the word "red" associated with "brave". Furthermore, Leech (1981) distinguishes associative meanings into; connotative, social, affective, reflective, and collocative meanings.

Connotative meaning is meaning that is not actual, generally satirical, and is a denotation meaning that has been added (Sutomo, 2015). It is used to present the condition associated with the word delivered, as a result of feeling association to the word heard or read (Dutamurty, 2013). For example "manis" on the sentence number (1), which lexically refer to something sweet such as "sugar", instead of the word "manis" on that sentence, defined as "beautiful" or "kind".

Social meaning is the meaning of a word that shows the user's social environment, such as a dialect that shows the origin of the speaker (Leech, 1981). Sutomo (2015) adds that social meaning refers to the style of word selection due to the existence of social differences and areas of activity in society. Examples: houses, huts, palaces, residences.

Affective meaning is the meaning that reflects the personal feelings of the speaker or writer, including his attitude to the listener, or his attitude to something he is talking about (Leech, 1981). It also refers to the sense to express our emotions, such as Aha! Aha! Or Yippee.

\section{(3) I'm sorry to interrupt}

Reflective meaning is the meaning that appears in multiple conceptual meanings when a sense of a word forms part of the response to another sense (Leech, 1981). It could be the meaning that appears is from the speaker when responding to what he sees. For example, fins have the reference meaning from fish.

Collocative meaning is associations of words that appear in the environment of another word (Leech, 1981). For example, pretty refers to girl, boy, woman, flower, garden, etc. while handsome refers to boy, man, car, etc. thus the word that can be formed such as "pretty girl", "pretty boy", "handsome boy" not "handsome girl".

\section{Thematic Meaning}

Thematic meaning is communicated by how a speaker or writer organizes the message in terms of the order, focus, and emphasis (Leech, 1981). It lies in the manner in which a message is organized for emphasis (Bagha, 2011). For further understanding, Leech (1981) gives an example of understanding the thematic meaning below.

(4) Mrs. Bessie Smith donated the first prize

(5) The first was donated by Mrs. Bessie Smith

Both sentences have different emphasizing. The active sentence is to answer the question What did Mrs. Bessie Smith donate? It emphasizes on the object. While the passive sentence is to answer Who was the first 
donated by? Or Who donated the first prize? This question refers to the subject. Thus, both sentences have different communicative value to deliver the context.

\section{METHOD}

The study used descriptive qualitative with content analysis to examine the contents of a document, by describing the problem, then analyzing and interpreting the data. This type of study can identify both real and implied messages of the documents studied (Bungin as cited in Sartika, 2014).

The data is collected from Facebook for a month, since $27^{\text {th }}$ of September 2018 to $28^{\text {th }}$ of October 2018.

The data collecting technique is an observation that involves all sensory forces such as hearing, sight, feeling, touch, and taste based on the facts of empirical events (Hasanah, 2017).

The researcher is observing ads on Facebook by using the reading technique and photo screenshot by using a mobile phone. All the ads that suspected as the fraudulent ads are taken. After the data are collected, the researchers chose the ads to analyze. The ads that do not have strong evidence as the fraudulent ads are eliminated.

The data validity uses expert judgment by consulting with the expert. Moreover, the researchers are only analyzing the word, sentence, or phrase that suspected as the way to convince the customer by following the theory of meaning (Leech, 1981).

\section{FINDING AND DISCUSSION}

From the observation that was held for a month, since $27^{\text {th }}$ of September 2018 to $28^{\text {th }}$ of October 2018, the researchers found two types of advertisement suspected as fraudulent ads.

The first ad is in Figure 2; it is suspected as the fraudulent ad because of lower prices. After conducting a recheck from the OLX (sales platform application), the price that the sellers offer around 27 th of September 2018 to $28^{\text {th }}$ of October 2018 is still above Rp. 5.000.000,00. Moreover, it is supported by the comment of the member that announced to be more careful with the ad.

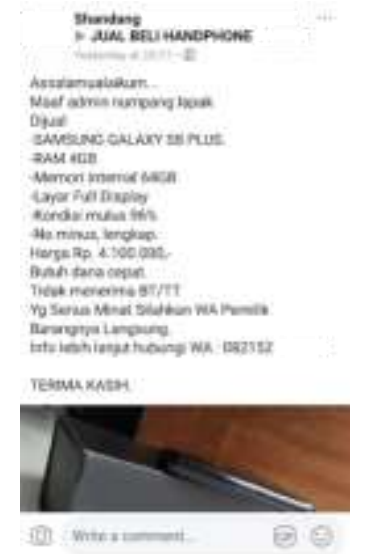

Figure 2. Suspected Ads (source: Facebook)

The second ad is in Figure 3; it is suspected as the fraudulent ad because of the prices which do not make sense, for example the price of Samsung Galaxy Note 9. From the recheck on 20th of December 2018, the price of Samsung released on Lazada (sales platform application) is Rp. 14.999.000,00, which is higher than the ads which only sale Rp. $850.000,00$.
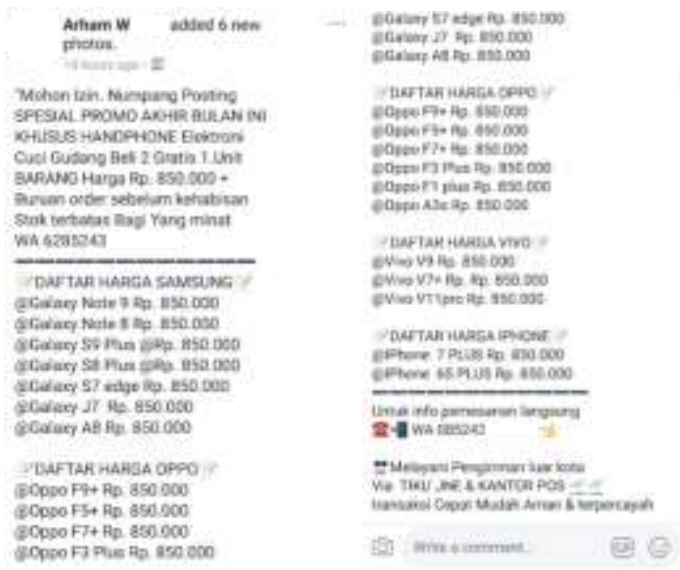

Figure 3. Suspected Second Ad (source: Facebook)

Some information from such ads has been censored to protect the possible use of photos or other people's name used by the fraudsters.

On the coding process, the researcher is labeled as first type or "Ft" for Figure 2. and Figure 3. is labeled as second type or "St", and the line is labeled as number. For example: "Ft/1-2" means the first type of ad on line 1-2.

Then, the researchers divided the ads' structure based on the structure that appeared from the ads found. The structure is divided into four parts that consist of opening, content or body of the ads, closing sentence, and illustration. Opening sentence in ads is usually 
started by greeting. Content or body of the ads is the content of advertisements which are usually in the form of detail or explanation of the products sell, prices, and contacts person. While closing is the sentence at the end of the ad and usually consists of closing word or slogans or even personal contacts. Illustration contains a picture of the product.

The next discussion will analyze the semantic feature mentioned by Leech (1981). The content analyzed in the advertisement is the linguistic feature, so the illustration is not included in it. Thus the content that analyzed is on the opening sentence, content, or body of the ads, closing sentence.

\section{Opening}

"Assalamualaikum, Maaf admin
numpang lapak". Translated as
"Assalamualaikum, sorry I'm
trading, admin [Ft/1-2]

"Assalamualaikum" is the greeting of Muslims containing social meaning. The use of that greeting is commonly used by someone who has good religion background because he/she knows it as good ethics taught by the prophet of Muhammad sallallaahu' alaihi wa sallam. Like the one hadist from Abu Hurairah radhiyallahu 'anhu (as cited in Tuasikal, 2018), he stated that the Prophet Muhammad sallallaahu' alaihi wa sallam stated, "Let the young give greetings to the older ones, let those who walk give greetings to those who are sitting, let little greetings to the many". Thus, someone who greets doing a suggestion from the prophet, even though sometimes the users do not know about the hadith.

Moreover, by greeting expression, the customers are expected to think that the seller is a good man who has good ethics and will not cheat the customers. Then, continued by "Maaf admin numpang lapak", which included to affective meaning. The seller asks the permission as politeness. The politeness refers to positive meaning.

\section{"Mohon Izin, Numpang posting". \\ Translated as "sorry, hitched a post" [St/1]}

On the second type, the seller used "mohon izin, numpang posting". The phrase contained affective meaning, which means as politeness. Same as the previous ad that the seller shows that he is a kind person. The use of this phrase is common to use in Facebook ads. Moreover, politeness is one of the important parts of selling. The use of politeness sentence can make the prospective customers feel more valued.

\section{Ads' Body or Content}

"Dijual, Samsung Galaxy S8 Plus, RAM 4 GB, Layar Full Display, Kondisi mulus 98\%, No minus, Lengkap, harga Rp 4.100.000, Butuh dana cepat, tidak menerima BT/ TT....". Translated as "On sale, Samsung Galaxy S8 Plus, RAM 4 GB, Full Display screen, smooth condition 98\%, No minus, Full set, price $R p$ 4.100.000, Need fast funds, do not accept BT / TT....." [Ft/3-13]

"Spesial promo akhir bulan ini, khusus handphone elektronik, cuci gudang, beli 2 gratis 1 unit...." Translated as "Special promo of the end of this month, specifically electronic cellphones, big sale, buy 2 free 1 units ..." [St/2-4]

"Buruan order sebelum kehabisan, stok terbatas...." Translated as "hurry up orders before it runs out, limited stock..." [St/6-7]

"Daftar harga Samsung, @galaxy note 9 Rp. 850.000...." Translated as “Samsung pricelist, @galaxy note 9 Rp. 850.000...."[St/9-10]

The content that is shown in the first type is very detail. "Samsung Galaxy S8 Plus, RAM 4 $G B$, Layar Full Display" is an explanation of the specification, referring to conceptual meaning. Those phrases are hard to suspect as kind of the phrase in the fraudulent ad because it explains the real specification. However, when reading at the price that offered " $R p$ 4.100.000" which continued by "butuh dana cepat" need to be watched out. This type of phrase is included to affective meaning, showing that the seller gives the lower price because the seller needs fast. The seller can sell with the higher price and get fast money if the seller offers to the cellphone counter, but he chose to offer and make the ad in facebook, which is wasting time.

It is different from the second type. The seller acts as he is a wholesaler giving an end of 
month promo. It was supported by some brands of phones list.

The use of "Buruan order sebelum kehabisan, stok terbatas" is one of the strategies to convince the customers. This phrase is included to thematic meaning; the seller writes the phrase by arranging the messages delivered in sequence and emphasizes the customers to buy fastly. This phrase also means that the seller always gets out of stock, so the customers must quickly contact the seller. The seller will communicate and convince the customers if the product offered is true by using a direct message.

Moreover, the use of "cuci gudang, beli 2 gratis 1 unit" is also included in thematic meaning. The seller is emphasizing to the buyer that the seller is doing big sale or flash sale. This phrase is used to attract customers' interest because many people like a gift. Whereas, all of that does not make sense because quoted from one brand which is SAMSUNG, in $20^{\text {th }}$ of December 2018, the price that Samsung released on Lazada is Rp. 14.999.000, which is higher than the ads which only sales Rp. 850.000 and also gives an extra gift.

\section{Closing Sentence}

\section{"Terimakasih" Translated as "Thank you" [Ft/16]}

"Terimakasih" is commonly used in Facebook ads which this word is included in the type of affective meaning. The use of "Terimakasih" has a relation with the greeting. Moreover, this also used as politeness.

"Transaksi cepat mudah aman \& terpercaya" Translated as "Fast, easy \& safe transactions" [St/35]

The second type chooses to use "Transaksi cepat, mudah, aman \& terpercaya" for closing sentence. This phrase is used to convince the customers if the seller is trusted. This type of phrase is included in thematic meaning. The seller reassures the buyers that the buyers do not need to worry about the transaction that will be carried out.

\section{CONCLUSION}

The first type of advertisement is emphasized to the affective and social meaning, where the seller leads the customers' opinion that he is a good person. However, the biggest suspicion arose in "butuh dana cepat" and the price offered was lower than the market. He can sell at a counter with the higher or equal price faster than he waits for an uncertain customer. Moreover, the seller uses a phrase that includes conceptual meaning to explain the condition or specification of the cellphone in detail.

In the second type of advertisement, the element emphasized by the seller is thematic mining by referring to the emphasis of the word used in the advertisement. Moreover, he tries to convince that he is a trusted seller. Besides, he also uses ways to provide additional gifts to attract customers.

In this study, researchers have not been able to explore more about preventive measures to identify the fraudulent ads that dominated through language. So in identifying fraudulent ads is dominated by the usual way, such as by looking at the price offered. However, the results of this study can also be used as a consideration in identifying fraudulent ads. One of the ways is, buyers need to be suspicious when the price offered in the product is low, and there is a phrase that stated: "buy one get one free". The buyer needs to conduct a recheck whether the other seller is doing the same thing or not. Besides, buyers also need to be suspicious when there are advertisements that contain the phrase "need fast funds", with prices offered is lower than market prices in general.

However, the results of this study can be used as a reference for further research interested in the semantic analysis of fraudulent ads. Thus, the other researchers need to continue this research to find a bright spot in identifying fraudulent ads through language. Then, the domination of language identification in the prevention of online fraud can be realized immediately.

\section{REFERENCES}

Arnani, M. (2018). 16.000 Laporan Diterima CekRekening.id, Penipuan "Online" Capai 14.000. Kompas.com. Retrieved from https://nasional.kompas.com 
Bagha, K. N. (2011). A Short Introduction to Semantics. Journal of Language Teaching and Research, 2(6), 1411-1419.

Baktiono, R. A., \& Artaya, I. P. (2016). Memilih Media Sosial Sebagai Sarana Bisnis Online Melalui Pendekatan Uji Categorical. 2(2)

Chaer, A. (2009). Pengantar Semantic Bahasa Indonesia. Jakarta: Rineka Cipta.

Chaer, A. (2009). Psikolinguistik: kajian teoritik. Jakarta: Rineka Cipta.

Dojosuroto, K. (2013). Pengaruh Pendekatan Pembelajaran dan Penguasaan Semantik Terhadap Peningkatan Pemahaman Makna Puisi: Studi Eksperimen Pada Mahasiswa Jurusan Pendidikan Bahasa dan Sastra Indonesia Fakultas Bahasa dan Seni Universitas Negeri Manado. Lingua. 9(1). 9-19.

Dutamurty, N. E. (2013). Associative Meaning on www. khilafah. com. Language Horizon, 1(2).

Hasanah, H. (2017). Teknik-teknik observasi (sebuah alternatif metode pengumpulan data kualitatif ilmu-ilmu sosial). At-Taqaddum. 8(1). 21-46.

Hastuti, S. (2011). Hubungan Pemanfaatan Situs Jejaring Sosial Facebook Dengan Penguasaan Mata Pelajaran Teknologi Informasi Dan Komunikasi (TIK) Pada Siswa Smp Negeri di Kotamadya Yogyakarta. Undergraduate Thesis. Universitas Negeri Yogyakarta: Yogyakarta.

Lazfihma. (2014). Analisis Gaya Bahasa Dalam Slogan Iklan Minuman Di Televisi. Undergraduate Thesis. Yogyakarta: Yogyakarta States University.

Leech, G. (1981). Semantics: The Study of Meaning (2nd ed.). Great Britain: Penguin Books.

Mardani, N. K., Martha, I. N., \& Putrayasa, I. B. (2017). Analisis Abreviasi dalam Iklan Baris Siswa Kelas 1X SMP Negeri 7 Singaraja. Jurnal Pendidikan Bahasa dan Sastra Indonesia Undiksha, 7(2).

Mushodiq, M. A. (2018). Tanda Peircean dan Maknanya dalam Unsur Intrinsik Cerpen 'Indama Ya'ti Al-Masa' Karya Naguib Mahfouz. Lingua. 13 (1). 9-19. 46-59.

Rinanda, Z. A. (2012). Analisis Struktur Kalimat Pada Wacana Iklan Brosur Provider Telekomunikasi. Undergraduate Thesis. Yogyakarta: Universitas Negeri Yogyakarta.

Sartika, E. (2014). Analisis Isi Kualitatif Pesan Moral dalam Film Berjudul "Kita Versus Korupsi”. Journal Ilmu Komunikasi. 2(2). 63-77.

Sumenge, M. (2013). Penipuan Menggunakan Media Internet Berupa Jual-Beli Online. Lex Crimen, 2(4). 102-112.

Sutomo, J. (2015). Konteks, Referensi, dan Makna: Kajian Semantik. Jurnal Ilmiah Dinamika Bahasa dan Budaya, 10(2).

Tuasikal, M. A. (2018). Tiga Hadits tentang Ucapan Salam. Retrivied from: https://rumaysho.com/18680-bulughul-maram-adab-tiga-hadits-tentang-ucapansalam.html. (30th of December 2018)

Verhaar, J. W. M. (2016). Asas-Asas Linguistik Umum. Yogyakarta: Gajah Mada University Press. 
LiNGUA Vol. 14, No. 1, Juni 2019 • ISSN 1693-4725 • e-ISSN 2442-3823

Watie, E. D. S. (2016). Periklanan dalam Media Baru (Advertising in The New Media). Jurnal The Messenger, 4(1), 37-43. 